\title{
Influence of Ang-(1-7) intervention on ACE2-Ang (1-7)-Mas pathway activity, hepatic glucose metabolism and insulin resistance in type-2 diabetic rats
}

\author{
Yufang Liu ${ }^{1}$, Fang Wang ${ }^{2 *}$, Xiue $X^{3}{ }^{3}$, Hui Cong ${ }^{4}$, Guiyan Chen ${ }^{5}$ \\ ${ }^{1}$ Department of Radiology, ${ }^{2}$ Department of Nuclear Medicine, The People's Hospital of Binzhou, Binzhou 256610, ${ }^{3}$ Department \\ of 3M, Yangxin TCM Hospital of Shandong Province, Yangxin 251800, ${ }^{4}$ Department of Pharmacy, Wudi People's Hospital, \\ Wudi 251900, ${ }^{5}$ Department of Endocrine, The People's Hospital of Binzhou, Binzhou 256610, China
}

*For correspondence: Email: vxg00w@163.com

Sent for review: 15 February 2019

Revised accepted: 29 April 2019

\begin{abstract}
Purpose: To study the effects of angiotensin-(1-7) (angiot (1-7) intervention on angiotensin converting enzyme (ACE)-angiot-(1-7)-Mas pathway, hepatic glucose metabolism, and insulin resistance in rats with type 2 diabetes.

Methods: Thirty-six Sprague Dawley rats were randomly divided into normal control, diabetic control and study groups (12 rats per group). Rats in the normal group were fed normal feed, while rats in the observation and diabetic control groups were type-2 diabetes model, and were given subcutaneous injection of angiot-(1-7) for 8 weeks. Serum insulin resistance index (IRI) and fasting insulin (FINS) were assayed. Other parameters measured were the levels of ACE2 and Mas receptor MRNA in liver tissues. Results: The levels of FINS in the study and control groups decreased, relative to normal control, while the levels of IRI was elevated $(p<0.05)$. There were significant increases in study group levels of Mas and ACE2, while angiot- $(1-7)$ was lower, relative to control group $(p<0.05)$. The expressions of ACE2 and Mas receptors in study and diabetic control rats groups were downregulated, when compared to normal control. The expressions of ACE2 and Mas receptors also decreased in the study group exposed to angiot- $(1-7)(p<0.05)$.

Conclusion: Angiot-(1-7) significantly increases the levels of FINS and IR, improves hepatic glucose metabolism and enhances ACE2-angiot-(1-7)-Mas pathway. Thus, angiot-(1-7) may be a new drug candidate for the treatment of type 2 diabetes.
\end{abstract}

Keywords: Angiotensin-(1-7), Type-2 diabetes mellitus, ACE2-ang (1-7)-Mas pathway, Liver metabolism, Insulin resistance

\begin{abstract}
This is an Open Access article that uses a fund-ing model which does not charge readers or their institutions for access and distributed under the terms of the Creative Commons Attribution License (http://creativecommons.org/licenses/by/4.0) and the Budapest Open Access Initiative (http://www.budapestopenaccessinitiative.org/read), which permit unrestricted use, distribution, and reproduction in any medium, provided the original work is properly credited.
\end{abstract}

Tropical Journal of Pharmaceutical Research is indexed by Science Citation Index (SciSearch), Scopus, International Pharmaceutical Abstract, Chemical Abstracts, Embase, Index Copernicus, EBSCO, African Index Medicus, JournalSeek, Journal Citation Reports/Science Edition, Directory of Open Access Journals (DOAJ), African Journal Online, Bioline International, Open-J-Gate and Pharmacy Abstracts

\section{INTRODUCTION}

Diabetes results from either defective insulin secretion or its impaired biological function [1]. Based on differences in pathogenesis, diabetes can be divided into type 1 diabetes and type 2 diabetes. Due to economic development and improvement of lifestyles, the population of type2 diabetic patients is increasing year by year, with most cases occurring after the age of 35 . 
The long-term treatment of diabetes seriously affects quality of life. It has been found that type2 diabetes is mainly due to insensitivity to insulin [2]. Insulin resistance (IR) is due to reduced uptake of insulin, resulting in hyperinsulinemia due to secretion of too much insulin to maintain the stability of blood glucose [3]. The reninangiotensin system (RAS) is a vital humoral regulatory system which can be decomposed into angiot-(1-7) under the action of prolyl peptide chain endonuclease and proline carboxypeptidase [4]. Angiotensin (1-7) [angiot-(1-7)] has a stronger effect on promoting aldosterone secretion. Studies have shown that RAS has a significant effect on IR development. Angiotensin converting enzyme 2 (ACE2) which exists in RAS as a negative regulatory pathway, mediates the ACE2-angiot-(1-7)-Mas pathway [5]. The GLUT15 is a bidirectional transporter [6]. In this study, the effect of angiot-(1-7) intervention on type 2 diabetes, ACE2-angiot-(1-7)-Mas pathway, hepatic glucose metabolism and insulin resistance was determined.

\section{EXPERIMENTAL}

\section{Animals}

Thirty-six (36) clean healthy male SD rats weighing $200 \pm 40 \mathrm{~g}$ were provided by Shanghai Ruitaimos Biotechnology Co., Ltd, Shanghai. This research was approved by the Animal Ethical Committee of Department of Nuclear Medicine, the People's Hospital of Binzhou, Binzhou (approval no. 201713577), and was carried out in line with "Principles of Laboratory Animal Care [7].

\section{Instruments and reagents}

The instruments and reagents used were blood glucose test strip and blood glucose meter (Omron Automation Co., Ltd., model: HEA-214); low temperature high speed centrifuge (Sigma, Germany, model 3-18K); centrifuge (Changsha Xiangrui Centrifuge Co., Ltd., model DT5-1B); streptozotocin (Sigma S0130); $0.9 \%$ sodium chloride injection (Chengdu Qingshan Likang Pharmaceutical Co., Ltd., specification: $100 \mathrm{ml}$ : $0.9 \mathrm{~g}$, production batch number: 2011120917); ang-(1-7) (Jill Biochemical Shanghai Co., Ltd.; ELISA kit, and PCR kit (Shanghai Thermo Fisher Scientific Co., Ltd.). Others were rabbit monoclonal antibody ACE2 (Epitomics, batch number: YH090805C); rabbit polyclonal antibody Mas (Gene Tex, Batch number: 821302279) and immunohistochemical staining kit (Beijing Spectrum Technology Co., Ltd.). Citrate buffer $(\mathrm{pH} 4.2$ - 4.5) was prepared fresh using citric acid and sodium citrate in a 1:1 ratio. Streptozotocin (STZ) was prepared in citrate buffer.

\section{Animal groups}

All rats were bred at laboratory temperature of $21 \pm 3{ }^{\circ} \mathrm{C}$, humidity of $48 \pm 12 \%$, and alternating 12-h light/12-h dark cycle, and fed adaptively for 2 weeks on standard rat feed. The rats had normal blood glucose before the experiment. Three rat groups were used viz: normal, diabetic control and observation groups (12 rats/group). The rats in the normal group were fed on basal diet. Rats in the normal control and study groups received high-calorie, high-fat, high-sugar diet (15\% protein, $37 \%$ carbohydrate and $48 \%$ fat; total calories $=20.55 \mathrm{KJ} / \mathrm{g}$ ) for 5 weeks. Thereafter, following an overnight fast, rats in the control and observation groups were injected intraperitoneally with STZ at the dose of 20 $\mathrm{mg} / \mathrm{kg}$ to prepare a type-2 diabetic rat model. Blood glucose was measured after 3 days via the tail vein. When the venous blood glucose was greater than $16.7 \mathrm{mmol} / \mathrm{L}$, and symptoms such as polydipsia, polyphagia, polyuria and weight loss were present, the diabetes model was successfully established. The observation rats group received neck injection of angiot-(1-7) subcutaneously. The normal and negative control were injected subcutaneously with an equivalent amount of $0.9 \%$ sodium chloride. After 8 weeks, the rat liver tissues were isolated, cleared of unwanted tissues and weighed. A plurality of liver tissues were preserved: some were stored frozen at $-80{ }^{\circ} \mathrm{C}$, while some were stored in formaldehyde, embedded in paraffin, stained and subjected to immunohistochemistry.

\section{Study parameters}

The rats were weighed after the treatment period, and their fasting blood glucose (FBG) was determined using blood glucose meter, while $\mathrm{HbA1c}$ was measured with glycosylated hemoglobin meter. The level of angiot-(1-7), insulin resistance index (IRI) \{i.e., $I R I=(F B G \times$ FINS)/22.5\}, insulin sensitivity index (ISI), free fatty acids (FFAs), liver glycogen (LG) and muscle glycogen (MG) were assayed using appropriate ELISA kits. Hexokinase (HK) was assayed colorimetrically, while ACE2 and Mas receptor mRNA in hepatic tissue were measured with PCR. The expressions of ACE2 and Mas protein were determined through immunohistochemistry.

\section{Statistical analysis}

Data analysis was performed with SPSS 20.0 software package. Independent sample $t$-test 
was employed for comparison of measurement data. Numeric data were compared with $\mathrm{X}^{2}$ test. Hierarchical data comparison was verified with Ridit. Values of $p<0.05$ were considered statistically significant.

\section{RESULTS}

\section{Weight, FBG and HbA1c}

Rat body weight in the diabetic control and observation groups were slightly decreased, relative to normal rats, but the levels of FBG and $\mathrm{HbA1c}$ were markedly increased $(p<0.01)$. The study group rats were a bit heavier than control rats, but their FBG and $\mathrm{HbA1c}$ levels were significantly reduced, relative to normal control ( $p$ $<0.01)$. These results are shown in Table 1.

Table 1: Weight, FBG and $\mathrm{HbA} 1 \mathrm{c}$ of the rats (mean \pm $\mathrm{SD}, \mathrm{n}=12$ )

\begin{tabular}{lccc}
\hline Group & Weight $(\mathbf{g})$ & $\begin{array}{c}\text { FBG } \\
(\mathbf{m m o l} / \mathbf{L})\end{array}$ & $\begin{array}{c}\text { HbA1c } \\
(\%)\end{array}$ \\
\hline Normal & $393.26 \pm$ & $4.91 \pm 0.53$ & $5.71 \pm$ \\
control & 2.55 & 1.91 \\
Diabetic & $257.45 \pm$ & $18.31 \pm$ & $10.69 \pm$ \\
control & 7.59 & 1.26 & 1.98 \\
Study & $269.34 \pm$ & $12.71 \pm$ & $8.49 \pm$ \\
F & 6.44 & 1.46 & 1.62 \\
$p$ & 13.119 & 10.647 & 22.465 \\
\hline
\end{tabular}

\section{Insulin resistance}

There were marked decreases in FINS and ISI in study and diabetic control rats, while IRI and FAA were markedly higher than corresponding normal control values $(p<0.05$; Table 2$)$. However, ISI and FAA were markedly higher in the study group $(p<0.05)$.

Table 2: Insulin resistance of the rats (mean $\pm S D, n$ $=12$ )

\begin{tabular}{lcccc}
\hline Group & $\begin{array}{c}\text { FINS } \\
(\mathbf{m I U} / \mathbf{L})\end{array}$ & ISI & IRI & $\begin{array}{c}\text { FAA } \\
(\mathbf{m m o l} / \mathbf{L})\end{array}$ \\
\hline Normal & $17.64 \pm$ & $-4.26 \pm$ & $3.84 \pm$ & $0.57 \pm$ \\
control & 1.63 & 0.92 & 0.59 & 0.15 \\
Diabetic & $8.14 \pm$ & $-5.44 \pm$ & $6.62 \pm$ & $0.88 \pm$ \\
control & 1.95 & 1.22 & 0.28 & 0.72 \\
Study & $9.92 \pm$ & $-4.78 \pm$ & $5.62 \pm$ & $0.64 \pm$ \\
$F$ & 0.45 & 0.94 & 0.88 & 0.21 \\
$p$ & 17.665 & 3.912 & 11.738 & 28.211 \\
& $<0.001$ & $<0.029$ & $<0.001$ & $<0.001$ \\
\hline
\end{tabular}

\section{Hepatic glucose metabolism}

As shown in Table 3, there was a marked increase in $M G$, and marked decrease in $L G$ levels in rats in the study group, relative to rats in the diabetic and normal control groups, while HK activity significantly increased in the study group, when compared with diabetic control and normal control groups $(p<0.001)$.

Table 3: Hepatic glucose metabolites of the rats (mean $\pm \mathrm{SD}, \mathrm{n}=12$ )

\begin{tabular}{lccc}
\hline Group & $\begin{array}{c}\text { MG } \\
(\mathbf{m g} / \mathbf{g})\end{array}$ & $\begin{array}{c}\text { LG } \\
(\mathbf{m g} / \mathbf{g})\end{array}$ & $\begin{array}{c}\text { HK (U/g } \\
\text { protein) }\end{array}$ \\
\hline Normal & $0.11 \pm$ & $11.27 \pm$ & $4.55 \pm 1.04$ \\
control & 0.08 & 1.39 & \\
Diabetic & $-0.39 \pm$ & $7.14 \pm$ & $2.51 \pm 1.08$ \\
control & 0.14 & 1.48 & \\
Study & $0.28 \pm$ & $9.41 \pm$ & $5.11 \pm 1.61$ \\
$F$ & 0.13 & 1.75 & \\
$p$ & 64.391 & 21.441 & 13.933 \\
\hline
\end{tabular}

\section{ACE2, angiot-(1-7) and Mas}

The results on Table 4 show that there were significant reductions in ACE2 and Mas receptors in the observation and diabetic control rats, relative to normal rats, while angiot-(1-7) level was markedly elevated ( $p<0.05)$. Moreover, study group expressions of ACE2 and Mas were significantly upregulated, when compared with those in diabetic control, but angiot-(1-7) was markedly lower in the diabetic control $(p<0.05)$. Expressions of ACE2 and Mas receptors in study and diabetic rats were lower, relative to normal rats $(p<0.05)$. These results are displayed in Figure 1, Figure 2, and Figure 3.

Table 4: Levels of ACE2, angiot-(1-7) and Mas in rats (mean \pm SD)

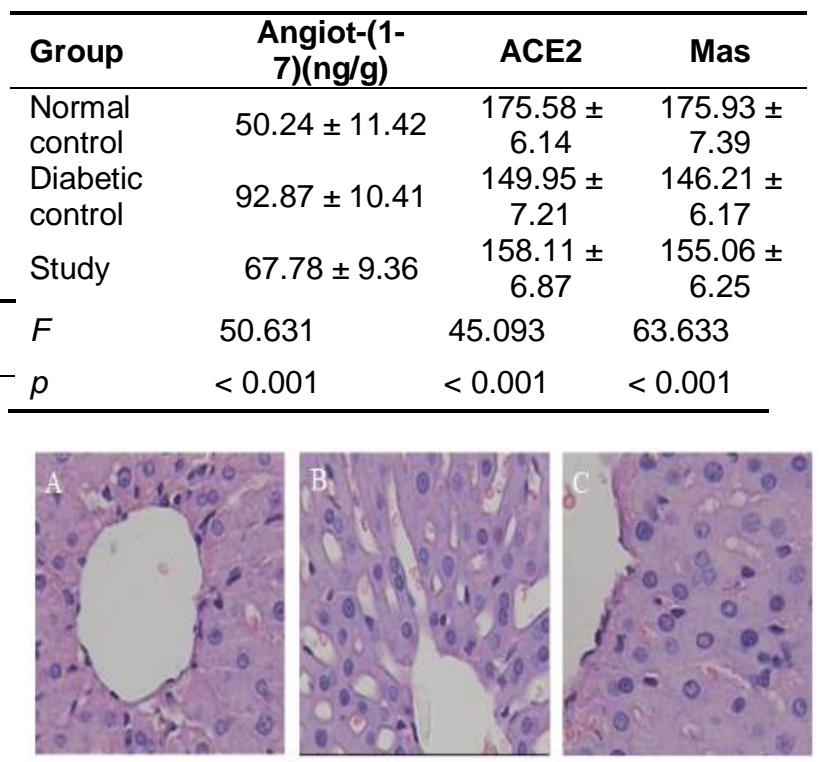

Figure 1: Liver photomicrography. A: normal control (NC); B: diabetic control (DC); C: study 


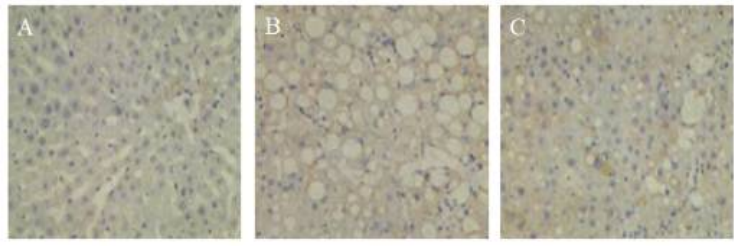

Figure 2: Hepatic ACE2 expression. A: NC; B: BC; C: study

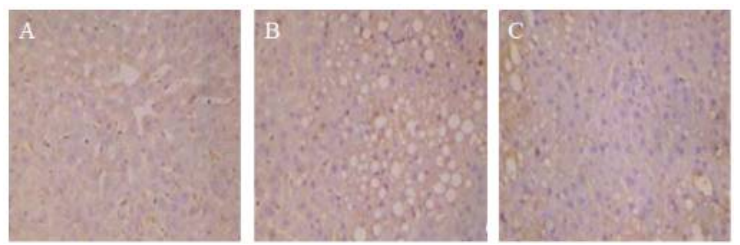

Figure 3: Hepatic expression of Mas. $A=N C ; B=$ $\mathrm{DC}$; and $\mathrm{C}=$ study group

\section{DISCUSSION}

Diabetes results in reduction in insulin intake and utilization of glucose, as well as a series of metabolic abnormalities characterized by elevated blood glucose [8]. Type-2 diabetes accounts for over $90 \%$ of diabetic cases. Insulinproducing capacity in patients with type-2 diabetes is not completely lost, but there is a state of relative lack of insulin [9]. Studies have shown that RAS blockers have inhibitory effects on adult-onset diabetes. The renin-angiotensin system (RAS) is present in normal liver, and its abnormal activation is closely related to IR [10].

RAS decomposes to produce angiot-(1-7) which binds to Mas receptor to antagonize angiot-II. A large number of studies have shown that the ACE2 - angiot-(1-7) - Mas pathway exerts blood vessel dilation and antithrombotic effects [11]. This research was carried out to study the influence of angiot-(1-7) on ACE2/angiot-(1-7) Mas route and liver metabolism of glucose in type-2 diabetic rats, in order to provide more theoretical basis for management of the disease.

One of the main manifestations of type-2 diabetes is IR. According to reports [12], the expression of angiot-II protein is significantly increased and the IR significantly improved in rats with ACE2 gene deficiency when fed on a high-calorie, high-fat, high-sugar diet. Angiotensin II improves liver metabolism-related gene expression. Studies have shown that angiot-(1-7) has an inhibitory effect on the expression of NAPDH oxidase gene in adipose tissue, which is mediated by insulin-induced glucose uptake to ameliorate IR [13].

Hexokinase is a key enzyme in glucose metabolism. The enzyme is coupled to GLUT4 on the cell membrane to increase its activity and promote LG synthesis. There were marked decreases in FINS and ISI in study and diabetic control group rats, while IRI and FAA were elevated, relative to normal rats. However, ISI and FAA were markedly higher in the study group. Thus, mitigation of IR by angiot-(1-7) was confirmed to regulate hepatic glucose metabolism.

In the classical RAS pathway (ACE-Ang II-ATIR), ACE hydrolyzes angiot-I to angiot-II which is the core effector of this pathway, and ACE2 decomposes angiot-II to produce angiot-(1-7, which can be over-expressed. Compensatory recovery of angiot-II-mediated pancreatic $\beta$-cell damage improves islet microcirculation and endothelial cell morphology, and also improves glucose tolerance [14].

Angiotensin (1-7) can be produced in a variety of ways, with a negative regulation of the RAS system. The Mas receptor is linked to $G$ protein. It is encoded by the Mas proto-oncogene, and is an endogenous conjugate of angiot-(1-7). It interacts with the Mas receptor and inhibits angiot-II-activated MAPK pathway [15]. The main features of type 2 diabetes are IR and islet beta cell function defects.

Studies have found that long-term high glucose status enhances the activity of RAS, thereby further impairing the structure and function of human islets. After blocking the effect of angiot(1-7), the secretion of FINS from rat islet $\beta$ cells was significantly reduced, further confirming that angiot-(1-7) treatment improves IR [16]. The ACE2 - angiot-(1-7) - Mas pathway affects the survival and function of islet beta cells. In the results of this study, there were significant reductions in ACE2 and Mas receptors in the observation and diabetic control rats, relative to normal rats, while angiot-(1-7) level was markedly elevated. Moreover, study group expressions of ACE2 and Mas were significantly upregulated, when compared with those in diabetic control, but angiot-(1-7) was markedly lower than those in the control group, and expressions of ACE2 and Mas receptors in study and diabetic rats were lower than those in the normal rats. Thus, angiot-(1-7) intervention in type 2 diabetic rats increases the activity of ACE2/angiot-(1-7)-Mas route and improves insulin resistance.

\section{CONCLUSION}

The results obtained in this study show that angiot-(1-7) inhibits the activity of RAS and antagonizes the action of angiot-Il. It also 
increases the levels of $M G$ and $L G$, improves liver glucose metabolism and reduces IR by regulating the expression of proteins related to the insulin signaling pathway. In addition, it increases the activity of ACE2-angiot-(1-7)-Mas pathway. However, there is a need to investigate the relationship between local RAS and circulating RAS in the liver.

\section{DECLARATIONS}

\section{Conflict of interest}

No conflict of interest is associated with this work.

\section{Contribution of authors}

We declare that this work was done by the author(s) named in this article and all liabilities pertaining to claims relating to the content of this article will be borne by the authors, all authors read and approved the manuscript for publication. Fang Wang conceived and designed the study, Yufang Liu, Fang Wang, Xiue Xu, Hui Cong, Guiyan Chen collected and analyzed the data. Yufang Liu wrote the manuscript.

\section{Open Access}

This is an Open Access article that uses a funding model which does not charge readers or their institutions for access and distributed under the terms of the Creative Commons Attribution License (http://creativecommons.org/licenses/by/ 4.0) and the Budapest Open Access Initiative (http://www.budapestopenaccessinitiative.org/rea d), which permit unrestricted use, distribution, and reproduction in any medium, provided the original work is properly credited.

\section{REFERENCES}

1. Craig ME, Hattersley A, Donaghue KC. Definition, epidemiology and classification of diabetes in children and adolescents. Pediatric Diabetes 2015; 15(20): 4-17.

2. Yu J. Clinical study of puerarin in the treatment of insulin resistance in patients with type 2 diabetes mellitus. Shandong J Tradit Chin Med 2015; 20(12): 727-729.

3. He JH, Liu H, Wang L, Wu HL, Dan N, Guo H, Li X. Effect and mechanism of angiotensin 1-7 on insulin resistance in type 2 diabetic rats. Chin J Med Clin 2017; 17(1): 1012.

4. Mori J, Patel VB, Alrob OA, Basu R, Altamimi $T$, Desaulniers J, Wagg CS, Kassiri Z, Lopaschuk GD, Oudit GY. Angiotensin 1-7 Ameliorates Diabetic
Cardiomyopathy and Diastolic Dysfunction in $\mathrm{db} / \mathrm{db}$ Mice by Reducing Lipotoxicity and Inflammation: Clinical perspective. Circ Heart Fail 2014; 7(2): 327-39.

5. Shenoy V, Ferreira A J, Qi Y, Fraga-Silva RA, Díez-Freire $C$, Dooies $A$, Jun JY, Sriramula $S$, Mariappan $N$, Pourang $D$, et al. The angiotensin-converting enzyme 2/angiogenesis-(1-7)/Mas axis confers cardiopulmonary protection against lung fibrosis and pulmonary hypertension. Am J Respir Crit Care Med 2017; 182(8):1065-1072.

6. Myint $\mathrm{H}$, Kishi $\mathrm{H}$, Koike $\mathrm{S}$, Kobayashi $Y$. Effect of chickpea husk dietary supplementation on blood and cecal parameters in rats. Anim Sci J 2017; 88(2): 372378.

7. World Health Organization. Principles of laboratory animal care. WHO Chron 1985; 39: 51-56.

8. Guo XH, Liu ZH, Li H, Li LS. Rat model of type 2 diabetes induced by high glucose and high fat diet and its characteristics of nephropathy. Chin Diabetes J 2017; 10(5): 290-294.

9. Maeda $N$, Shimomura I, Kishida $K$, Nishizawa $H$, Matsuda M, Nagaretani $H$, Furuyama $N$, Kondo $H$, Takahashi $M$, Arita $Y$, et al. Diet-induced insulin resistance in mice lacking adiponectin/ACRP30. Nat Med 2014; 8(7): 731-737.

10. Li YC, Qiao G, Uskokovic M, Xiang W, Zheng W, Kong J. Vitamin $D$ : a negative endocrine regulator of the reninangiotensin system and blood pressure. I Steroid Biochem Mol Biol 2014; 89(1-5): 387-392.

11. Chen $Z Q, X u$ J, Guo Q, Ma EW, Bai L, Ma Y, Jia R, Zhang $\mathrm{JH}$. Effect of Huatan Tongluo traditional Chinese medicine on angiotensin converting enzyme 2angiotensin (1-7)-Mas axis in renal cortex of diabetic nephropathy rats. Chin J Integr Tradit Chin West Med 2014; 34(06): 714-721.

12. Sun $L P$, Huo LJ, Zhang $Y Y$. Effects of valsartan on ACE2, Angll and Ang (1-7) in rats with hepatic fibrosis. Int J Dig Dis 2013; 33(2): 128-131.

13. Yu X, Cui L, Hou F, Liu X, Wang Y, Wen Y, Chi C, Li C, Liu $R$, Yin $C$. Angiotensin-converting enzyme 2angiotensin (1-7)-Mas axis prevents pancreatic acinar cell inflammatory response via inhibition of the p38 mitogen-activated protein kinase/nuclear factor-kB pathway. Int J Mol Med 2018; 41(1): 409-420.

14. Xun $Y$, Qin YF, Xu MJ, Huang $Y$. Research progress of ACE2-Ang-(1-7)-Mas axis on glucose metabolism. Guangdong Med J 2015; (1): 150-153.

15. Xu P, Sriramula S, Lazartigues E. ACE2/ANG-(1-7)/Mas pathway in the brain: the axis of good. Am J Physiol Regul Integr Comp Physiol 2015; 300(4): 804-817.

16. Román CL, Maiztegui B, Del Zotto $H$, Gagliardino JJ, Flores LE. INGAP-PP effects on $\beta$-cell mass and function are related to its positive effect on islet angiogenesis and VEGFA production. Mol Cell Endocrinol 2017; 470: 269-280. 